\title{
TRANSACTIONS
}

OF THE

SAN DIEGO SOCIETY OF NATURAL HISTORY

Vol. VI, No. 26, pp. $389-390$

August 28, 1931

\section{A NEW SUBSPECIES OF PEROMYSCUS FROM THE GULF COAST OF LOWER CALIFORNIA, MEXICO}

\author{
BY \\ Laurence M. Huey \\ Curator of Birds and Mammals, San Diego Society of Natural History
}

The species Peromyscus crinitus is at present known in Lower California only from suitable and very limited areas on the desert mountains in the northern part of the peninsula. Through the recent purchase of a small collection of mammals from the vicinity of Gonzaga Bay, situated in latitude $29^{\circ} 50^{\prime}$, on the eastern coast of Lower California, a series of six specimens of an apparently new race of this mouse has been acquired by the San Diego Society of Natural History. This may be known as:

Peromyscus crinitus pallidissimus subsp. nov.

Lower California Canyon Mouse

Type.-From a small island in Gonzaga Bay, Lower California, Mexico, lat. $29^{\circ} 50^{\prime}$ north, long. $114^{\circ} 20^{\prime}$ west; no. 8864 , collection of the San Diego Society of Natural History; adult male; collected by A. W. Anthony, November 21, 1930; original number 1175 .

Characters.-In size, this race resembles Peromyscus crinitus stephensi, but is paler and lacks much of the buffy underparts found in stephensi. The dark overcast of the back is much paler than stephensi. Cranially, this new race has a slightly flattened brain case compared with stephensi, though here also measurements are nearly alike.

Range.- Known from the type locality, as above, and from San Felipe, on the east coast of Lower California, to the northward. Specimens from the latter locality are not typical, but they are nearer to pallidissimus than to specimens of stephensi found in the vicinity of the International Boundary. 
Remarks.-The accompanying map shows the position of the small island upon which the type series was taken. The island is unnamed, although designated as "Willard Point" on U. S. Navy Hydrographic Office Chart No. 619. It is worthy of note that this is the first occurrence of crinitus in an insular locality.

Specimens examineil.-Peromyscus crinitus stephensi: Lower California, Mexico, 1 (Signal Mountain); San Diego County, California, 4 (1 from Mountain Springs; 3 from Mouth of Palm Canyon, Borego Valley); Inyo County, California, 8 ( 4 from Pleasant Canyon, Panamint Mountains; 1 from Onyx Mine, 10 miles west of Ballarat, Panamint Valley; 3 from Orondo Mine, Argus Mountains); Yuma County, Arizona, 4 (Tinajas Altas). Peromyscus crinitus pallidissimus: Lower California, Mexico, 37 (31 from San Felipe; 6 from Gonzaga Bay, type locality).

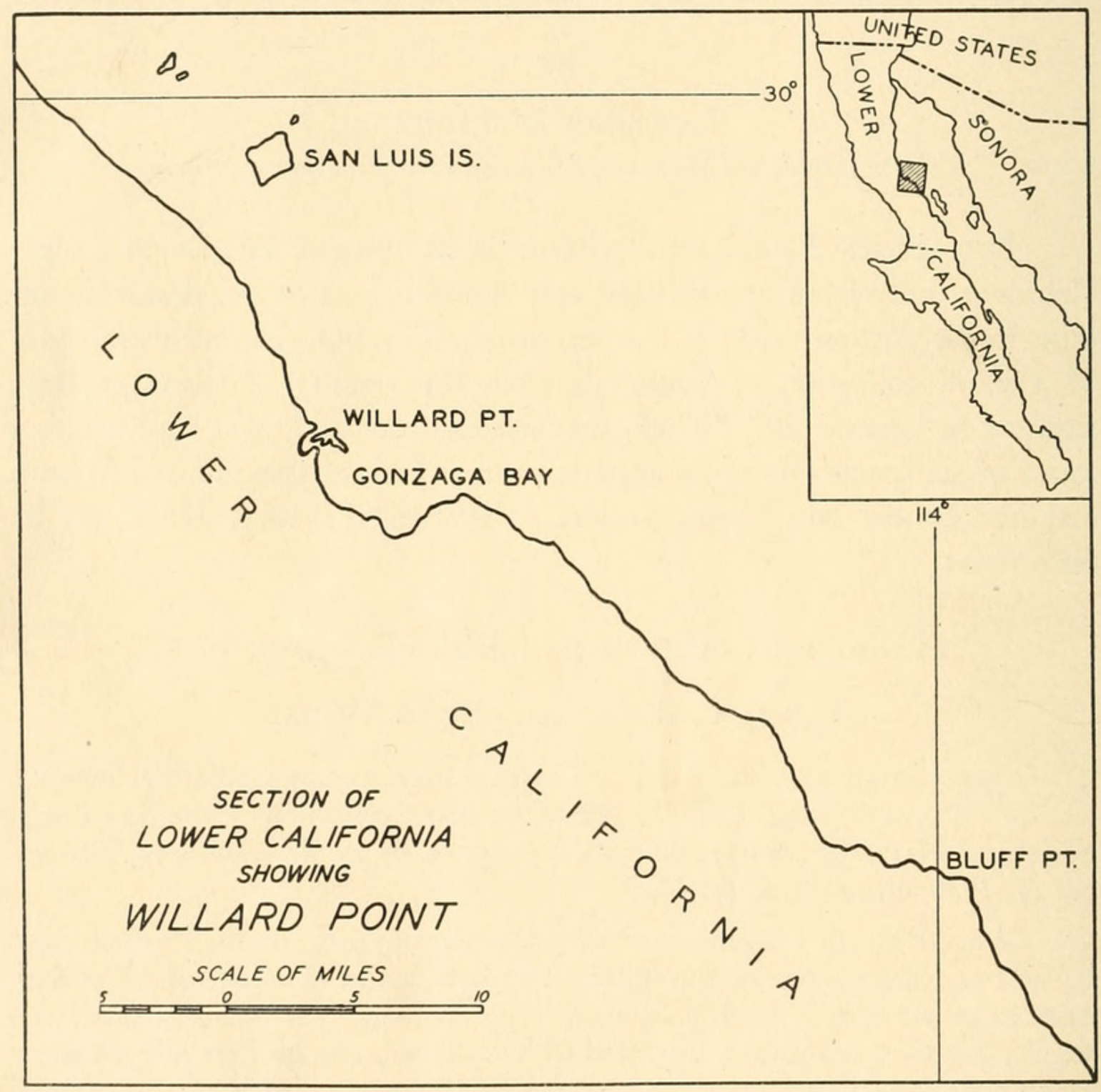




\section{$2 \mathrm{BHL}$ Biodiversity Heritage Library}

1931. "A new subspecies of Peromyscus from the Gulf Coast of Lower California, Mexico." Transactions of the San Diego Society of Natural History 6, 389-390. https://doi.org/10.5962/bhl.part.11701.

View This Item Online: https://www.biodiversitylibrary.org/item/28523

DOI: https://doi.org/10.5962/bhl.part.11701

Permalink: https://www.biodiversitylibrary.org/partpdf/11701

\section{Holding Institution}

Harvard University, Museum of Comparative Zoology, Ernst Mayr Library

\section{Sponsored by}

Harvard University, Museum of Comparative Zoology, Ernst Mayr Library

\section{Copyright \& Reuse}

Copyright Status: In copyright. Digitized with the permission of the rights holder.

License: http://creativecommons.org/licenses/by-nc-sa/3.0/

Rights: https://biodiversitylibrary.org/permissions

This document was created from content at the Biodiversity Heritage Library, the world's largest open access digital library for biodiversity literature and archives. Visit BHL at https://www.biodiversitylibrary.org. 